\title{
Effects of Xylene on Respiratory Mucosa in Rats
}

\author{
Efectos del Xileno sobre la Mucosa Respiratoria de Ratas
}

\author{
Arslan Eda*; Samanci Baver.**; Samanci Bölükbasi Seyla***; Özevren Hüseyin ${ }^{* * * *}$ \& Deveci, E.*****
}

ARSLAN, A.; SAMANCI, B; SAMANCI, B. S; ÖZEVREN, H. \& DEVECI, E. Effects of xylene on respiratory mucosa in rats. Int. J. Morphol., 34(3):934-938, 2016.

SUMMARY: In this study we examined the effects histopathologic and immunohistochemical of xylene inhalation in rats by using light microscopy. Adult wistar albino rats were used in this study. Eight rats were in control group and 8 rats were in the experimental group. The experimental group was exposed to $300 \mathrm{ppm}$ formaldehyde $3-5 \mathrm{~min} /$ day, 5 days/week for 8 weeks. The lining epithelium of respiratory mucosa showed a loss of ciliated cells with metaplasia of goblet cells, hyperplasia of squamous cells and edema, inflamation in sub epithelial area). In the group treated xylene. Disruption of cell-cell contact was observed. Weak expression of E-cadherin was observed between cells. The vascular endothelium of capillaries and venoles showed intense immunostaining for VEGF.

KEY WORDS: Xylene; Vascular endothelial growth factor; E-Cadherin; Respiratory mucosa.

\section{INTRODUCTION}

Inhalation of xylene is a dangerous type of exposure to this chemical. The common side effect of inhaled xylene is depression of the central nervous system causing dizziness, headache, nausea and vomiting. Irritation of the nose and throat may also occur with low-level inhalation of xylene (Shifko, 2015). Histopathological technicians who routinely come in contact with xylene-contaminated solvents in the workplace are the population most likely to be exposed to high levels of xylene. The current Occupational Safety and Health Administration permissible exposure limit for xylene is $100 \mathrm{ppm}$ as an 8-h time-weighted average (TWA) concentration (Occupational Safety \& Health Administration, 2015). Irritation of the nose and throat can occur at approximately $200 \mathrm{ppm}$ after 3-5 min. Accidental splash in the eye may damage the surface of the eye, which will heal within a few days (Agency for Toxic Substance and Disease Registry, 1993). Cell-cell adhesion plays an important role in tissue morphogenesis and is commonly mediated by cadherins, a family of $\mathrm{Ca}^{2+-}$ dependent transmembrane adhesion receptors (Gumbiner, 1996). Ecadherin is one of the best-characterized transmembrane glycoproteins expressed on many types of epithelial cell surfaces, including nasal epithelium (Takeichi, 1988; Alberts et al., 1994; Lüning et al., 1994).VEGF stimulates the endothelial cells lining nearby microvessels to proliferate, to migrate, and to alter their pattern of gene expression (Yancopoulos et al., 2000). In this study, a chemical agent such as xylene, nasal mucosal cell-cell contact and impact it has made on angiogenesis investigate by immunohistochemistry.

\section{MATERIAL AND METHOD}

Wistar rats (180-200 g body weight) used in these trials were divided into two groups of 16 animals each (Control group and Experimental group). The rats were obtained from the Department of Medical Science Application and Research centre of Dicle University. All the animals were individually housed in stainless steel cages at room temperature. The animals had free access to standard laboratory rat pellet and water. $100 \times 65 \times 100$ in the sizes of the experimental group were taken into a glass vase. During

* Department of Otorhinolaryngology, Head and Neck Surgery, Education Research Hospital of Ankara, Ankara, Turkey.

** Department of Otorhinolaryngology, Head and Neck Surgery, Academy of Hospital, Diyarbakır, Turkey.

*** Department of Otorhinolaryngology, Head and Neck Surgery, Education Research Hospital of Selahaddin Eyyubi, Diyarbakir, Turkey.

***** Department of Neurosurgery, Dicle University School of Medicine, Diyarbakir, Turkey.

****** Department of Histology and Embryology, School of Medicine, University of Dicle, Diyarbakir, Turkey. 
the time period of 8 weeks, 5 days a week with 3-5 min the inhalation of $300 \mathrm{ppm}$ xylene (Li et al., 1986) was made. Xylene vapor in the environment,with a special air pump ventilation constant volume,pressure and temperature achieved (Pabst, 1987).

Tissue preparation for light microscopy. The skin as well as all the soft tissues surrounding the nasal cavity were removed. Then, the bony-framework of the nasal cavity including the nasal septum was nibbled out with a bone-nibbler. The samples were fixed with neutral buffered formalin solution and decalcified with $5 \%$ EDTA (Ethylenediaminetetraacetic acid). After preservation, nasal samples were directly dehydrated in a graded series of ethanol then the sections were stained with Hematoxylene-Eosin (H-E)

Immunohistochemical staining. Antigen retrieval process was performed in citrate buffer solution ( $\mathrm{pH}$ 6.0) two times: first $7 \mathrm{~min}$, and later $5 \mathrm{~min}$ boiled in a microwave oven at 700 $\mathrm{W}$. The slides were allowed to cool to room temperature for $30 \mathrm{~min}$ and washed in distilled water for $5 \mathrm{~min}$ two times. Endogenous peroxidase activity was blocked in $0.1 \%$ hydrogen peroxide for 15 min. Ultra V block (Cat. No: 859043, Invitrogen, Carlsbad, CA, USA) was applied for $10 \mathrm{~min}$ prior to the application of primary antibodies (E-cad antibody, mouse monoclonal, 1/200, Santa Cruz) and (VEGF antibody, mouse monoclonal, 1/100, Santa Cruz) overnight. Secondary antibody (Cat. No: 85-9043, Invitrogen, Carlsbad, CA, USA) was applied for $20 \mathrm{~min}$. Slides were then exposed to streptavidin-peroxidase for $20 \mathrm{~min}$. Diaminobenzidine (DAB, Invitrogen, Cat. No: Invitrogen, Carlsbad, CA, USA) was used as a chromogen. Control slides were prepared as mentioned above but omitting the primary antibodies. After counterstaining with Hematoxylin, washing in tap water for $5 \mathrm{~min}$ and in distilled water twice for $5 \mathrm{~min}$, the slides were mounted.

\section{RESULTS}

In control group, no histopathologic changes were seen (Fig. 1A). As a result of the 8-week inhalation of xylene; The lining epithelium of respiratory mucosa showed a loss of ciliated cells with metaplasia of goblet cells, hyperplasia of squamous cells and edema, inflamation in sub epithelial area. There was vacuolation and hydropic degeneration in seromucous glands (Fig. 1B). In another section of xylene group dilatation and hemorrhagia showed in blood vessels and increase in inflamatory cells (Fig. 1C). In the control group, negative VEGF expression showed in endothelial cells but positive expression in some connective cells (Fig. 2A). In the group treated xylene, the vascular endothelium of

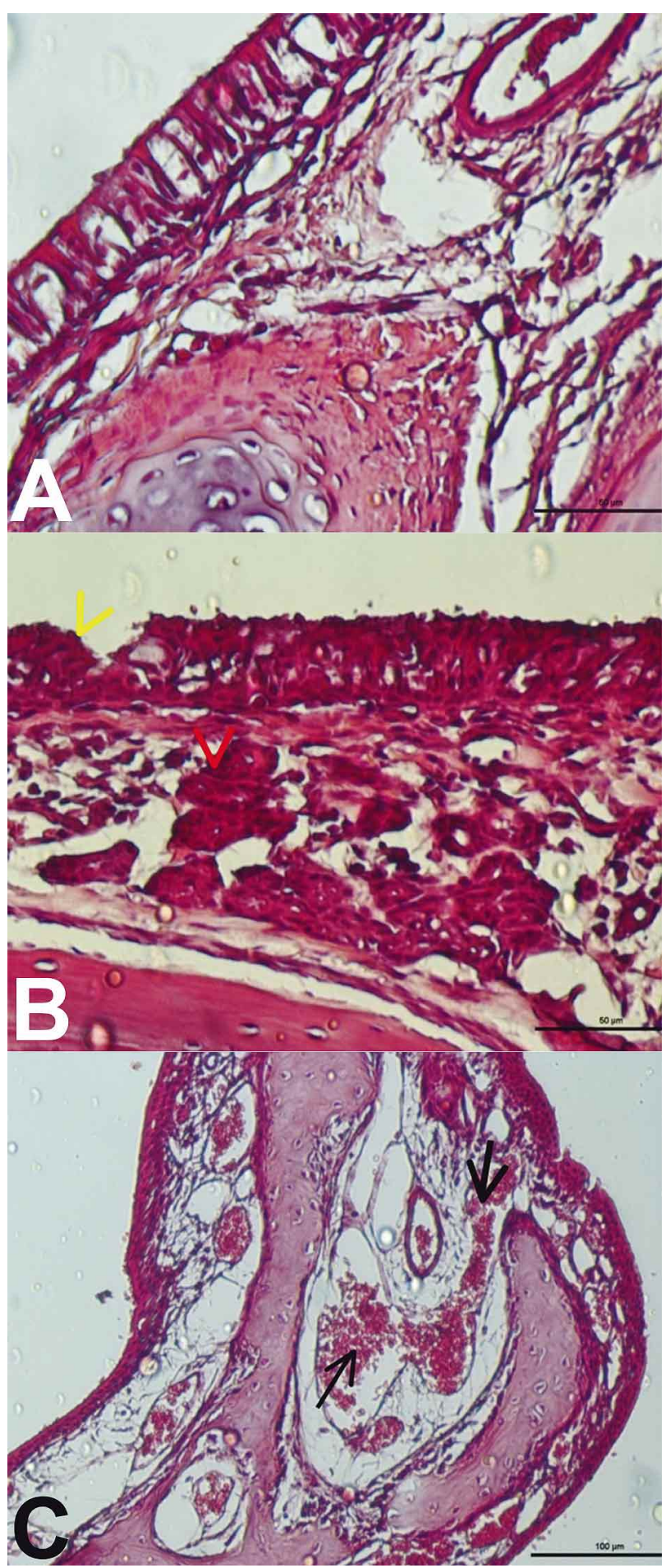

Fig. 1. A) Control group, normal appearance of epithelial cells and goblet cells (H-E staning, Bar $50 \mu \mathrm{m}$ ). B) Section of group treated xylene; loss of cilia in apical surface (arrow), degeneration in epithelial cells, necrotic changes in seromucous glands (arrow) and edema in subepithelial area (H-E staning, Bar $50 \mu \mathrm{m}$ ). C) Another section of group treated xylene, dilatation and intense hemorrhage in blood vessels of nasal concha (arrow) a increase in inflammatory cells (H-E staining, Bar $100 \mu \mathrm{m}$ ). 
capillaries and venoles showed intense immunostaining for VEGF. VEGF immunoreactivity was present in inflammatory cells (Fig. 2B). E-Cadherin positive expression was observed in the area of cell-cell contact. Basal and apical face increased expression of E-cadherin (Fig. 3A) In the group treated xylene disruption of cell-cell contact was observed. Weak expression of E-cadherin was observed between cells. The results of our study showed that exposure to xylene inhalation, cause histopathologic changes. such as: epithelial necrosis, exfoliation and cilia loss subepithelial leukocyte cell infiltration of rat respiratory mucosa epithelium as well.

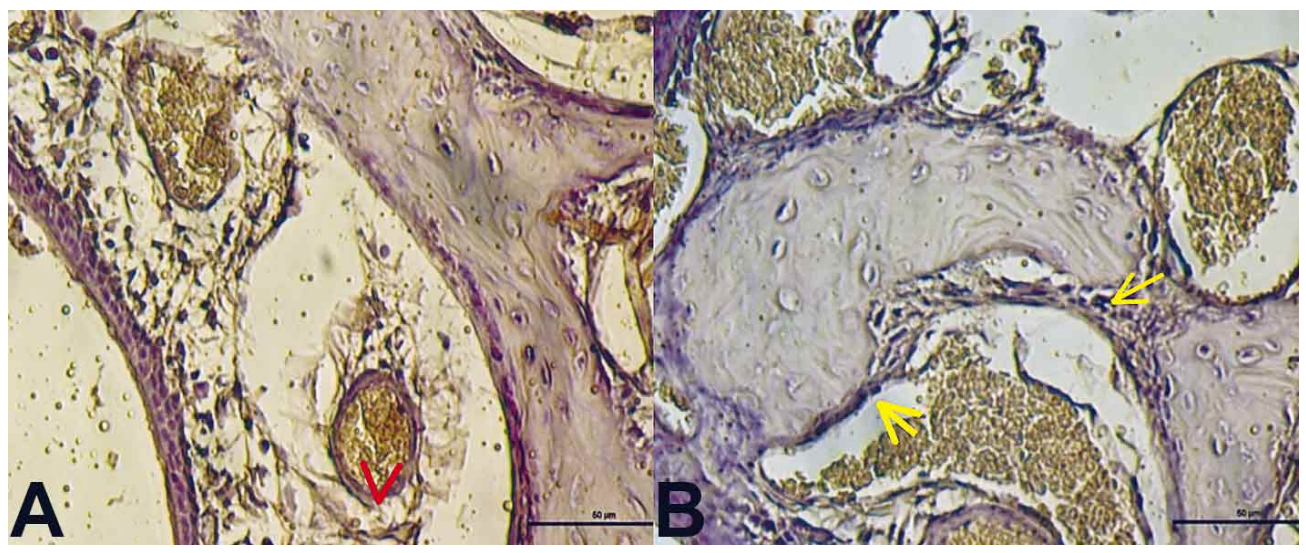

Fig. 2. A) Control group, negative VEGF expression in endothelial cells of blood vessels (arrow) (VEGF immunostaining, Bar $100 \mu \mathrm{m})$. B) Positive VEGF expression in endothelial cells and inflammatory cells (arrow), negative VEGF expression in nasal bone cells (VEGF immunstaining, Bar $50 \mu \mathrm{m}$ ).

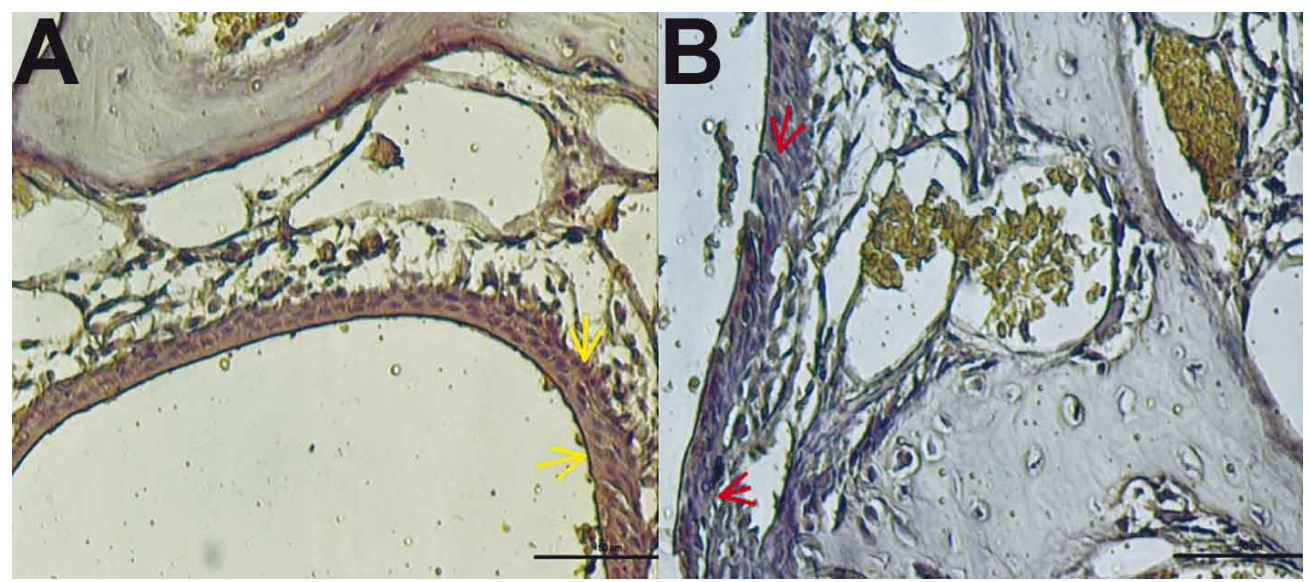

Fig. 3. A) Control group, E-Cadherin positive expression in the area of cell-cell contact (arrow). Positive E-cadherin expression in apical face and basal membrane (E-cadherin immunostaining, Bar $100 \mu \mathrm{m})$. B) Section of group treated xylene; Disruption of cell-cell contact and weak expression of E-cadherin (arrow) (E-Cadherin immunostaning, Bar $50 \mu \mathrm{m}$ ).

\section{DISCUSSION}

Xylene is a hydrocarbon known for its wide usage in tissue processing, staining in the histology laboratory. Exposure occurs primarily by inhalation. The volatility and lipophilicity of the xylenes make the lung and nasal mucosa the primary target organs (Vaidyanathan et al., 2003).
In the study, we observed that xylene leads to degenerative changes. Epithelial cells and glands necrosis, cilia loss subepithelial leukocyte cell infiltration of rat respiratory mucosa were observed. The epithelial response to injury may depend on the xylene, the severity of the injury, and the presence of inflammatory cells and necrosis in 
glands. Xylene causes an irritant effect on the respiratory tract and alters its functional activity and cellular morphology. The principal morphologic lesion in rats exposed to $300 \mathrm{ppm}$ xylene was a marked, chronically active rhinitis.

The epithelial barrier function is provided by the formation of intercellular junctions. E-cadherin is an important molecule in the maintenance of epithelial integrity (Takeichi, 1990). The airway epithelium plays a role in immune regulation during environmental challenge, which is intertwined with its barrier function and capacity to limit submucosal access of environmental factors. Damage to the epithelium may result in loss of E-cadherin membrane expression and intercellular contacts (Nawijn et al., 2011). E-cadherin contributes to the structural function of airway epithelium, through the regulation of epithelial junctions, proliferation, that can modulate the immune response. In our study we observed that E-cadherin expression was significantly decreased in xylene group, as compared to nontreated group. We concluded that xylene might affect the cellular junctions in the nasal mucosa. Cell-cell junctions are important to maintain cell and tissue polarity. One of the functions of vascular endothelial growth factor (VEGF) is increasing vascular permeability. VEGF is implicated in several other pathological conditions associated with enhanced angiogenesis or enhanced vascular permeability, such as rheumatoid arthritis (Koch et al., 1994). Matsune et al. (2010) reported that VEGF is present in nasal secretions in rhinosinusitis, particularly in allergic rhinitis, and is hyperproduced immediately after antigen provocation. It was concluded that vascular endothelial growth factor is intensely expressed, mainly in inflammatory cells and in endothelial cells.

This suggests that vascular endothelial growth factor, inducing edema and angiogenesis, could be involved in the pathogenesis of nasal damage.

ARSLAN, A.; SAMANCI, B; SAMANCI, B. S; ÖZEVREN, H. \& DEVECI, E. Efectos del xileno sobre la mucosa respiratoria de ratas. Int. J. Morphol., 34(3):934-938, 2016.

RESUMEN: Se examinó el efecto histopatológico e inmunohistoquímico de la inhalación de xileno en ratas mediante el uso de microscopía de luz. Se utilizaron ratas albinas Wistar adultas. Ocho ratas formaron parte del grupo control y 8 del grupo experimental. El grupo experimental fue expuesto a 300 ppm de formaldehído, 3-5 min/día, 5 días/semana, durante 8 semanas. El epitelio de revestimiento de la mucosa respiratoria mostró una pérdida de células ciliadas con metaplasia de células caliciformes, hiperplasia de células escamosas y edema, con inflamación en la zona subepitelial. En el grupo tratado con xileno se observó una interrupción del contacto célula-célula. Se observó una débil expresión de E-cadherina entre las células. El endotelio vascular de los capilares y vénulas mostraron intensa inmunotinción de VEGF.

PALABRAS CLAVE: Xileno; Factor de crecimiento vascular endotelial; E-cadherina; Mucosa respiratoria.

\section{REFERENCES}

Agency for Toxic Substance and Disease Registry (ATSDR). Toxicological Profile for Xylene. Atlanta, Agency for Toxic Substance and Disease Registry, U. S. Department of Health \& Human Services, 1993.

Alberts, B.; Bray, D.; Lewis, J.; Raff, M.; Roberts, K. \& Watson, J. D. Molecular Biology of the Cell. New York, Garland, 1994. pp.950-1010.

Gumbiner, B. M. Cell adhesion: the molecular basis of tissue architecture and morphogenesis. Cell, 84(3):345-57, 1996.

Koch, A. E.; Harlow, L. A.; Haines, G. K.; Amento, E. P.; Unemori, E. N.; Wong, W. L.; Pope, R. M. \& Ferrara, N. Vascular endothelial growth factor. A cytokine modulating endothelial function in rheumatoid arthritis. J. Immunol., 152(8):4149-56, 1994.
Li, G. L.; Yin, S. N.; Watanabe, T.; Nakatsuka, H.; Kasahara, M.; Abe, H. \& Ikeda, M. Benzene-specific increase in leukocyte alkaline phosphatase activity in rats exposed to vapors of various organic solvents. J. Toxicol. Environ. Health, 19(4):581-9, 1986.

Lüning, C.; Rass, A.; Rozell, B.; Wroblewski, J. \& Obrink, B. Expression of E-cadherin during craniofacial development. $J$. Craniofac. Genet. Dev. Biol., 14(4):207-16, 1994.

Matsune, S.; Ohori, J.; Yoshifuku, K. \& Kurono, Y. Effect of vascular endothelial growth factor on nasal vascular permeability. Laryngoscope, 120(4):844-8, 2010.

Nawijn, M. C.; Hackett, T. L.; Postma, D. S.; van Oosterhout, A. J. \& Heijink, I. H. E-cadherin: gatekeeper of airway mucosa and allergic sensitization. Trends Immunol., 32(6):248-55, 2011. 
Occupational Safety \& Health Administration (OSHA). Air Contaminants Occupational Safety and Health Administration. Washington D. C., United States Department of Labor, 2005. Available from: http://www.osha.gov/comp-links.html

Pabst, R. Exposure to formaldehyde in anatomy: an occupational health hazard? Anat. Rec., 219(2):109-12, 1987.

Shifko, R. Harmful Effects of Xylene. Lifestrong.com, 2015. Available from: http://www.livestrong.com/article/101063harmful-effects-xylene/

Takeichi, M. Cadherins: a molecular family important in selective cell-cell adhesion. Annu. Rev. Biochem., 59:237-52, 1990.

Takeichi, M. The cadherins: cell-cell adhesion molecules controlling animal morphogenesis. Development, 102(4):63955,1988 .

Vaidyanathan, A.; Foy, J. W. \& Schatz, R. Inhibition of rat respiratory-tract cytochrome P-450 isozymes following inhalation of m-Xylene: possible role of metabolites. J. Toxicol. Environ. Health A, 66(12):1133-43, 2003.

Yancopoulos, G. D.; Davis, S.; Gale, N. W.; Rudge, J. S.; Wiegand, S. J. \& Holash, J. Vascular-specific growth factors and blood vessel formation. Nature, 407(6801):242-8, 2002.
Correspondence to:

Prof. Dr. Engin Deveci

Department of Histology and Embriyology

Faculty of Medicine

Dicle University

Diyarbakir

TURKEY

Email: engindeveci64@gmail.com

Received: 13-11-2016

Accepted: 14-04-2016 